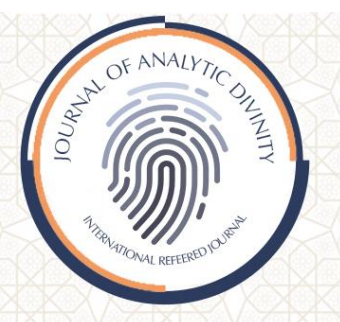

\author{
Journal of Analytic Divinity \\ International Refereed Journal \\ E-ISSN: 2602-3792 \\ Nisan/ April 2021/ 5 (1): ss-pp 89/110
}

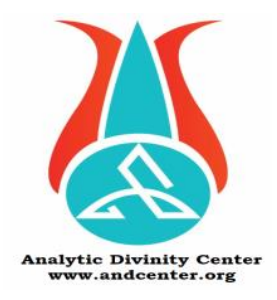

\title{
Planlı Davranış Teorisi Bağlamında Kur'an'da Niyet
}

Intention in the Quran in the Context of Theory of Planned Behavior

\section{Seda Müjdeci}

Ankara Yıldırım Beyazıt Üniversitesi İslami İlimler Fakültesi Ankara Yıldırım Beyazıt University Faculty of Islamic Sciences

\author{
Ankara/Turkey,sdmjdc@gmail.com \\ https:// orcid.org/ 0000-0003-0658-1371
}

\begin{abstract}
Makale Bilgisi | Article Information
Makale Türü / Article Type: Derleme Makale/ Review Article
\end{abstract}

Geliş Tarihi / Date Received: 19 Ocak/ January 2021

Kabul Tarihi / Date Accepted: 11 Nisan / April 2021

Yayın Tarihi / Date Published: 15 Nisan /15 April 2021

Yayın Sezonu / Pub Date Season: İlkbahar-Nisan/ Spring-April

DOI: $10.46595 /$ jad. 865013

Cite as / Atıf: Müjdeci, Seda. "Planlı Davranış Teorisi Bağlamında Kur'an'da Niyet", Journal of Analytic Divinity, 5/1 (April 2021): 89-110.

Intihal: $\mathrm{Bu}$ makale, iThenticate yazılımınca taranmıştır. İntihal tespit edilmemiştir. Plagiarism: This article has been scanned by iThenticate. No plagiarism detected. Web: http://dergipark.gov.tr/jad | e-mail to: editorjand@gmail.com

Copyright $(\subset$ Published by Özcan Güngör, Ankara Yıldırım Beyazıt Üniversitesi, İslami İlimler Fakültesi / Ankara Yıldırım Beyazıt University, Faculty of Islamic Studies, Ankara-Turkey. Bütün hakları saklıdır. / All right reserved. 


\title{
Öz
}

İnsan davranışlarının kaynağını oluşturan etmenlerin daha iyi anlaşılması için oluşturulan teorilerden bir tanesi Ajzen ve Fishbein tarafından geliştirilmiş olan planlı davranış teorisidir (PDT). Planlı davranış teorisi sayesinde bir davranışın ortaya çıkma ihtimali tahmin edilebilmekle beraber davranışa yönelik amaç belirlenebilir. Aynı zamanda bu teoriye göre kişilerin davranışlarına etki eden en önemli faktör niyettir. Niyet denilince daha çok akla ibadetlerin gerçekleştirilmesi veya kalplerdeki iyi ya da kötü yöndeki arzular gelmektedir. Bunlar doğru olmakla beraber planlı davranış teorisinde kastedilen niyet bir davranışın gerçekleşmesi veya gerçekleşmemesi doğrultusunda kişinin davranışlarının sonuçlarını düşünerek; tutum geliştirmesi, sosyal baskıdan etkilenmesi ve davranışsal kontrol ile hareket etmesidir. İslam dininde ise niyet, istenilen bir şeyi amaçlamada kalbin istenilen şeyde karar kılması ve davranışların meydana gelmesinin kilit noktalarından bir tanesidir. Dolayısıyla bu çalışmanın amacı niyetin Kur'an'da ele alınmasını planlı davranış teorisinin temelini oluşturan "tutum", "algılanan sosyal baskı" ve "algılanan davranışsal kontrol" başlıkları altında Kur'an' daki etkileşimleriyle ayetler ışığında incelemektir. Kur'an'da niyetin ele alınması ile planlı davranış teorisi arasında ilişkinin kurulabileceği örnek metinler bulgulanmıştır. Çalışma tarihsel dokümantasyon tekniğine uygun olarak işlenmiş̧tir.

Anahtar Kavramlar: Planlı Davranış Teorisi, Niyet, Sosyal Psikoloji, Kur'an, İslam Sosyolojisi.

\begin{abstract}
One of the theories created to better understand the factors that make up the source of human behavior is the theory of planned behavior (TPB) developed by Ajzen and Fishbein. The probability of occurrence of a behavior can be predicted, and intention of the behavior can be determined through theory of planned behavior, At the same time, according to this theory, intention is the most important factor which has influence upon people's behavior. When we say intention the first thing come to our mined more is the realization of prayers or the good or bad desires in the hearts. These are true though, the intention meant in theory of planned behavior is to consider the consequences of the person's behavior toward realization or non-realization of a behavior; developing an attitude, being affected by social pressure and acting with behavioral control. In an islamic concept intention is one of the key concept for the heart to decide on the desired thing and the occurrence of behavior in aiming at something desired. Therefore, the purpose of this reserch is to study the bestowment of intention in the Quran under the headings of "attitude", "perceived social pressure" and "perceived behavioral control" in the light of verses with its interplay in the Quran. Exemplary texts that can discover a relationship between the bestowment of the intention and the theory of planned behavior have been found in the Quran. The reserch has been processed according to the historical documentation technique.
\end{abstract}

Keywords: Theory of Planned Behavior, İntention, Social Psychology, Quran, Sociology of İslam. 


\section{Giriş}

İnsan davranışlarına yön veren etkenlerin var olduğu ve bu davranışları önceden tahmin etmek düşüncesi, psikolojik çalışmaların temelini oluşturmuştur. Bununla beraber birçok sosyal-psikolojik teorinin ortaya atılması ve geliştirilmesi ihtiyacı hissedilmiştir. Kişilerin davranışlarını oluşturma yahut sergileme kararına etki eden birçok faktör bulunmaktadır. Dolayısıyla sosyal psikolojinin temel konularından birini oluşturan tutumlar, hem sosyal algımızı hem de davranışlarımızı etkilemektedir. Tutumların oluşmasına etki eden unsurlar mevcuttur. Bunlardan biri de dini inançlar dolayısıyla Kur'an'dır. İnsanların dini inançlara olan bağlllıkları olumlu ya da olumsuz yönde tutum geliştirmelerine etki eder. Tutum, gözle görünür ya da sergilenen bir davranış olmayıp tam anlamıyla davranışın kendisine hazırlayıcı bir eğilimdir (Kağıtçıbaşı \& Cemalcılar, 2014, 129-130). Bu bağlamda tutumu konu edinen planlı davranış teorisi, Bamberg'e göre büyük sıklıkla kullanilan sosyal psikoloji teorisidir. Piles ve Schmidt ise bu teorinin sosyal psikoloji içerisinde davranışların açıklanması yönünde deneysel açıdan en geniş alanlarda test edilen ayrıca çok iyi sonuç veren bir teori olduğunu söylemişlerdir (Mercan, 2015, 2). Planlı davranış teorisi, sosyal psikoloji temelli bir kuram olmasının yanı sıra birçok farklı dal ve disiplinin alanına giren davranışları beyan etmede yaygın bir şekilde kullanılmıştır (Cohen ve Hanno, 1993 akt. Öztürk vd. 2015, 145-146).

Planlı davranış teorisi ${ }^{1}$ ve İslam dininde niyet kavramına² ilişkin ayrı ayrı olmak üzere yapılan çalışmalar vardır. Ancak her iki konunun bir arada bulunduğu Kur'an merkezli herhangi bir çalışmaya rastlanılmamıştır. Dolayısıyla bu çalışmada planlı davranış teorisinin temelini oluşturan niyet kavramı ile bu niyetlere etki eden unsurların, dini bağlamda, Kur'an ayetleri ışığında nasıl ele alındığı ve örnekler üzerinde yorumlandığı sorusuna cevap aranmıştır. Verilen örnek ayetler, planlı davranış teorisinin her bir unsurunun kendi özelliği bağlamında ayrı ayrı ilişkilendirilerek çalışılmıştır.

Çalışmanın konusu planlı davranış teorisi bağlamında niyet kavramının Kur'an'i boyutlarını psikososyal açıdan ele almaktır. İslam düşünce geleneğinde "niyet" kavramı ile planlı davranış teorisini oluşturan ve yönlendiren etmenlerin benzerliği, her iki kavramın birbirleri ile ilişkilendirilebileceğini göstermektedir. Bu bağlamda çalışmanın temel amacı, Kur'an'da niyet kavramını planlı davranış teorisinin temelini oluşturan a) davranışa yönelik tutum, b) algılanan sosyal baskı ve c) algılanan davranışsal kontrol unsurları bağlamında incelenmesidir.

\footnotetext{
${ }^{1}$ Konuya ilişkin ayrıntılı literatür okumaları için bkz. (Öztürk vd., 2015, 141-160; Göktürk, 2019).

2 Konuya ilişkin ayrıntılı literatür okumaları için bkz. (Zeydân, 1976, 216-228; Çetintaş, 2014, 51-70; Türker vd., 2017; Şavlı, 2018, 305-320).
}

Journal of Analytic Divinity, https://dergipark.org.tr/tr/pub/jad Volume 5/1 
Davranışlarımızın kaynağını oluşturan planlı davranış teorisinin temel yapı taşı olan niyet kavramını incelemek, bu davranışların hangi tutum ve prensipler içerisinde meydana geldiğini, neleri etkilediğini açılamak ve bunu Kur'an ayetleri doğrultusunda incelemek araştırmanın perspektifi açısından oldukça önemlidir.

Çalışma tarihsel dokümantasyon tekniğine uygun olarak bilgi, belge ve içerikler yolu ile elde edilmiştir. Kavramların psikososyal boyutları incelenirken sözlüklere, alan yazınındaki kitap, makale ve tezlere; Kur'an ayetlerinin değerlendirmelerinde ise Kur'an meali, aynı zamanda anlaşılamayacağı öngörülen noktalarda farklı birçok tefsire müracaat edilmiştir. Veriler, anlayıcı yaklaşım perspektifinden gruplandırılarak amaç ve alt amaçlar bağlamında kullanılmıştır.

\section{Planlı Davranış Teorisi}

Planlı Davranış Teorisi, mantıklı eylem teorisinin bir uzantısı olarak öne sürülen; Ajzen ve Fishbein tarafınca geliştirilmiş, insan eylemlerini ve bu eylemleri oluşturan asıl etmenlerin ön görülmesi ve açıklanması üzerine oluşturulmuş bir teoridir. Kişilerin genel olarak akla göre hareket ettikleri, var olan bilgileri göz önünde bulundurdukları ve herhangi bir davranışın neticesinde açık ya da kapalı olarak değerlendirdikleri hipotezine dayanan planlı davranış teorisi, kişinin davranışı meydana getirme niyetinin bu davranışın en güçlü belirleyicisi olduğunu savunmaktadır (Ajzen \& Fishbein, 2005, 173). Ayrıca davranış üzerinde etkili olabilecek hareketleri açılamaya yönelik geniş boyutlu bir teoridir (Karahan, 2018, 47). Planlı davranış teorisi, insan davranışlarının oluşumuna etki eden belli nedenlerin olduğu hipotezini savunur. Kişiler, meydana getirdikleri eylemlerin oluşturduğu neticeleri önceden analiz eder ve düşünür. Üzerinde düşünülen eylemlerin sonuçları arasında bir tercihte bulunup karara varır ve bunu uygularlar. Belli bir niyet sonucu meydana gelen eylemlerde amaç, analiz edilen ve üzerine düşünülen sonuca ulaşmaktır. Dolayısıyla bu teoriye göre bir davranışa direkt etki eden tutum değil, niyettir. Tutum, niyete etki ederken, niyet de davranışa etki etmektedir (Kağıtçıbaşı \& Cemalcılar, 2014, 141). Kişinin bir durum karşısındaki tutumu, sonradan yapılması planlanan davranışın kaynağı olan niyeti oluşturmaktadır. 
Ajzen'ne göre PDT, aşağıda verilmiş olan tablo gibidir.

Tablo 1 PDT Modeli

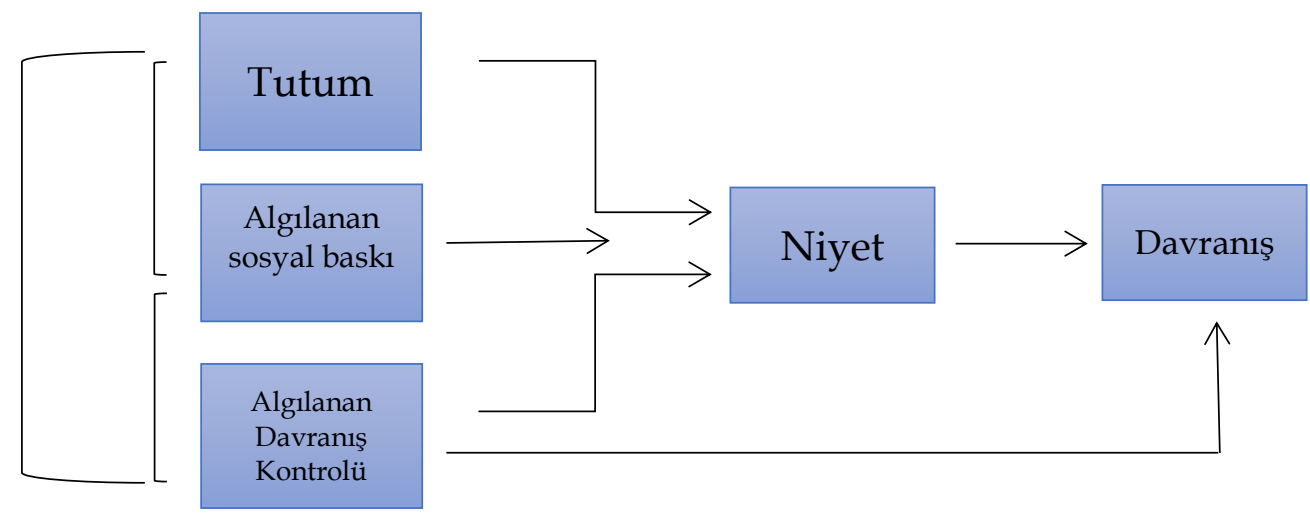

(Ajzen, 2006).

Planlı davranış teorisi, kişilerin toplumsal davranışlarının bazı unsurların kontrolü altında bulunduğunu; belli nedenlerden meydana geldiğini bu bağlamda da planlı olarak ortaya çıktığını öne sürmektedir. Bu sebeple bireydeki davranışa yönelik niyetin oluşması gerekir (Tekkaya vd. 2011, 640). Niyetin oluşumuna etki eden faktörler ise insanın "davranışa yönelik tutumu", "algılanan sosyal baskı" ve "algılanan davranışsal kontrol" dür (Ajzen, 1991, 182). Bir davranışı sergilemenin pozitif veya negatif yönde bir değerlendirmesi bulunduğunu savunan Ajzen'e göre, davranışa yönelik tutumları, davranışsal inançlar ve davranışsal değerlendirme belirlerken; öznel normları, normatif inançlar ve uyma güdüsü sınırlandırır; algılanan davranışsal kontrolü ise kontrol inançları ve kontrol unsurlarının gücü belirlemektedir (Ajzen, 1991, 179-183). Öyle ki, davranışların oluşmasına etki eden etkenler, kişinin davranışlarının sonuçlarını öngörerek sergilemesini veya sergilememesini etkiler.

\section{Niyet Kavramı}

Niyet, "bir şeyi (davranış, düşünce vs.) yapmayı önceden isteyip düşünme, maksat anlamlarına gelmektedir" (TDK, 20 Aralık 2020). Niyetin sözlük anlamı ise kalbin anında veya sonrasında kendi amacına uyumlu gördüğ̈ü yani kendisi için bir fayda veya zarar teşkil edeceğine inandığı davranışa doğru yol alması veya karar kılmasıdır (Dönmez, 2007, 169).

Niyet, bireylerin ilgili davranışı sergileme ya da sergilememe yönündeki temayüllerini ve tasarımlarını oluşturur (Küçük, 2011, 147). Esasen niyet, insan fiillerinin 
meydana gelmesinde veya sergilenmesinde en muazzam unsurdur (Yüzüak, 2017,17). Dini ve felsefi düşünce geleneklerinde de fiile önem arz eden ve onu anlamlı kılan faktör olarak değerlendirilen niyet, hem dindarlığın hem de ahlâklı olmanın anlamı hususunda belirleyici güce sahiptir (Türker vd. 2017, xi). Niyetin terim olarak tanımında ise âlimler, davranışa bağlı olarak bir şeyi gerçekleştirmeyi istemek şeklinde ifade etmişlerdir (Zeydân, 1976, 217).

Kişinin kalpte bulunan bir çıkarın veya zararın peşinen yahut ileride temin edilmesi ya da giderilmesi amacına uygun olduğunu düşündüğü şeye doğru meyletmesi olan niyete din şu anlamı vermiştir, "Allah'ın isteğini umarak ya da onun emrine sarılarak davranışa yönelen iradedir. Niyet dilde azimdir; dinde ise yüce Allah için davranışı amaçlamaktır" (Tehânevî, 1996, 1735 akt. Türker vd. 2017, 6-7). Fiilleri meydana getirmek için bireylerin ne kadar çaba harcama tasavvurlarını ve ne kadar çaba göstermeye talip olduklarına dair göstergeleri olan niyetlerin bir fiile dokunan isteklendirme unsurlarını yakaladığı varsayılmaktadır (Yetim, 2019, 13).

İslâm dininde yüklenmiş olduğu mana ve rol itibariyle bir diğer ibadetlerin ruhunu oluşturan niyet, İslam ibadet fıkhında önemli bir yere sahiptir (Şavlı, 2018, 307). Aynı zamanda insan kalbinin iradi olarak bir davranışa meyletmesi ve sadece yaratıcının emirleri doğrultusunda onun rızasını kazanmaya çalışmasıdır (Sandıkçı, 2018, 359). Dolayısıyla niyet İslam dininde ibadetler noktasında ve yapılan işlerin ardındaki asıl amaç ve irade açısından büyük öneme sahiptir.

\section{Kur'an Bağlamında Davranışa Yön Veren Tutum ve Niyet}

Tutum, kişinin bir mesele, konu, nesne, fiil vb. ile ilgili olumlu veya olumsuz yöndeki değerlendirmesi ve bu değerlendirmelere göre belirli bir biçimde davranma eğilimidir (Koç, 2013, 272). Davranışa yönelik tutum, davranışı ortaya koyacak kişinin, o davranışın meydana gelmesine karşı pozitif veya negatif yöndeki değerlendirmesidir (Erten, 2002, 222). Tutumların ardında inançlar da mevcuttur. Kişinin bir nesne üzerine sahip olduğu olumlu inançlar ise o nesneye karşı olumlu bir tutum oluşturmaktadır. Böylece kişinin o davranışı gerçekleştirme niyeti ve eğilimi yüksek olmaktadır (Türkmen, 2015, 41). Eğer tam tersi bir durum söz konusu ise kişinin davranışı gerçekleştirme eğilimi beklenen düzeyin altında olur.

Kur'an'da "niyet" kavramı açık bir şekilde yer almamakla birlikte En'âm Suresi 95. ayette geçmekte olan "en-nevâ" kelimesi kendisiyle aynı kökü paylaşır. "En-nevâ" kavramı Arapçada; tohum, çekirdek anlamlarına gelmekle beraber ayette anlatılmak istenen Allah'ın, kudretiyle yardığı çekirdek veya tohumun patlayarak filiz vermesi ve türlü türlü bitkileri, tatları vs. meydana getirmesi, doğanın canlanmasıdır (Karaman vd. 2017, 444). Bu 
bağlamda küçük bir tohumun toprakta saklı olması gibi niyette kalplerde gizlidir. Öyle ki, toprak altındaki küçük tohumdan ormanlar meydana geldiği gibi doğru olan küçük bir niyetten olumlu yönde davranışlar ve salih ameller oluşur.

Dini inançlar, bireylerin tutum geliştirmesine etki eden önemli unsurlardan bir tanesidir. İslam dinine göre Müslüman bir birey kendisine rehberlik eden Kur'an yolunda tutum ve davranışlara sahip olmalı ve bu bağlamda bir davranışı sergilemeden önce süzgeçten geçirmelidir (Öztürk vd. 2015, 146). Dolayısıyla kendilerini Müslüman olarak tanımlayıp İslam dininin vermiş olduğu emirleri ve yasakları benimseyen kişilerin, davranışlarını sergilerken bu emir ve yasaklara karşı olumlu bir tutum içinde olmaları beklenir. Olumsuz tutum içinde olmaları karşısında ise bu durumun doğuracağı sonuçlar kısmen de olsa tahmin edilmelidir.

\subsection{Niyeti Yönlendiren Ahlâki Tutumlar}

Kur'an'da niyet her şeyin başı, fiillerin arkasında olan asıl neden yani özüdür (elMülk 67/2; el-Kehf 18/110; el-Beyyine 98/5). Kur'an-1 Kerim'in birçok ayetinde niyetin önemine vurgu yapılmakla birlikte kavramsal olarak niyet, ahlâki davranışların başlangıcı kabul edilmektedir (Gündüz, 2019, 308). Ahlâk, kişilerin davranışlarını ayrıca birbirleriyle ilişkilerini değerlendirmek amacıyla başvurulan kurallar bütünü; kişilerin davranışlarını pozitif ve negatif yönde yargılamakta kullanılan ölçütlerdir (Subaşı, 2014, 190). Ahlâk, davranışların ana modeli olmakla birlikte insan davranış ve ilişkilerinin değerlendirilmesi ile ilgilidir (Vatandaş, 2011, 66). Gazâli'ye göre ahlâk, insan nefsinde var olan öyle bir yetidir ki bu sayede bireyin davranışları, bir zorlama olmaksızın rahatça ortaya çıkar; ondan iyi davranışlar ortaya çıkarsa bu iyi/güzel ahlâk olur, kötü davranışlar ortaya çıkarsa da kötü/çirkin ahlâk olur (Gazâli, 1987, 125).

Kişinin ahlâk üzerindeki tutumları, onun davranışlarını sergileyip sergilememe noktasındaki kararlarını doğrudan etkiler. Müslüman bir kişiye tutumlarında etki eden unsurlardan biri Kur'an'dır. Kur'an, bireye ve topluma yönelik davranışların nasıl oluşturulması gerektiği noktasında bazı ikazlarda (ahlâki davranışlar) bulunarak dikkat çekmiştir (el-Bakara 2/172; en-Nisâ 4/49; Nûr 24/21). Kur'an'da insanlara yönelik dini sorumlulukların gerçekleştirilmesi doğrultusunda ahlâki zaruretlere bakıldığında, kişi veya kişilerin ahlâki bir tutum göstermeleri beklenir (Güngör \& Şahin, 2017, 29). Gösterilen olumlu tutumlar davranışa etki eden niyetlerin de olumlu yönde oluşması sonucuna ulaştıracaktır. Olumsuz tutumlar ise niyetin olumsuz yönde oluşmasına ve ahlâki davranışların bu yönde tezahür etmesine sebep olacaktır. Müslüman bir bireyin İslam'ın vurguladığı ve önemsediği kuralları benimsemesi, davranışlarını sergilerken ahlâki kurallara olumlu bir tutum içerisinde olması beklenir. Bu doğrultuda örnek verilirse kişilerin nasıl bir ahlâki tutum sergilemeleri gerektiğini açıklayan Kur'an'da adil olmak, alçak gönüllülük, anneye babaya hürmet, sevgi, sulh, güven, arayı düzeltmek, sahihlik, iyilik ve merhamet (en-Nisâ 4/58-128-135; el-Furkan 25/63; el-İsrâ 17/23; el-Enfâl 8/61; el-

Journal of Analytic Divinity, https://dergipark.org.tr/tr/pub/jad Volume 5/1 
Hucurât 59/10; el-Bakara 2/224-283; et-Tevbe 9/119; el-Mâide 5/93; er-Rûm 30/21) gibi birçok güzel ahlâki davranışlara sevk eden bununla beraber zulmetmekten, dedikodu yapmaktan, bencillikte bulunmaktan, kin gütmek gibi kötü kalp ve niyetlerden (Âl-i İmrân 3/140; Kaf 50/18; el-Haşr 59/9-10; el-Bakara 2/225) yol çevirmeyi vurgulayan ayetlerin bulunması ile gidilmesi gereken yönü göstermektedir. Nitekim Kur'an'ın insanlara gösterdiği bu yönün aynı zamanda Hz. Peygamber'de de vuku bulması ile şöyle ifade edilmiştir: "Sen elbette üstün bir ahlâka sahipsin." (el-Kalem 68/4). Dolayısıyla verilen ayetler, Kur'an'ın ahlâki niyetlere ne denli kıymet verdiğinin apaçık bir göstergesidir. Ayette bahsedilen "üstün ahlâk" insanlara yol gösteren Kur'an' in kendisidir (Karaman vd. 2017, 429-430). İşte bunların hepsi ahlâki tutuma etki eden etmenlerdir. Bu sebeple şu söylenebilir, Müslüman bir bireyin ahlâk çerçevesi içerisinde yer alan bu kaidelere olan tutumu, onu kullanma niyetini olumlu etkiler ve davranışlarını o doğrultuda sergiler. Ahlâki davranışların sergilenebilmesi ise niyetin yahut o eylemi gerçekleştirme sebebinin de belirtilen kötü düşünce ve davranışlarından uzak durması ile mümkündür. Bu tutumlar neticesinde oluşan davranışlar kişinin dini inançlarını kuvvetlendirir ve bu bağlamdaki tutumlarını olumlu yönde geliştirmesine katkı sağlar.

\subsubsection{Ahlâki Tutumun Oluştuğu Kurum Aile}

İnsanın zamanla değişmekte olan rol modeli, dünyaya geldiği anda ilk olarak üyesi olduğu ailedir. Bu bağlamda en temelde kişi, topluma ait yazısız normları (örf-adet ve gelenek-görenek), birçok ihtiyacın nasıl giderilmesi gerektiğini, dini öğretileri öncelikle ailesinden alır (Güngör, 2016, 56-61). Aile, insanın tutum ve davranışları üzerinde etkili olan bir mihenk taşıdır. Kişi, ailesini yani içinde doğup büyüdüğü aile bireylerini örnek almakta ve gördükleri neticesinde bir durum veya davranışa karşı olumlu ya da olumsuz yönde tutum geliştirebilmektedir. Kur' an' da 127 yerde "ehl" ifadesiyle geçmekte olan aile kavramı, bu bakımdan ilk sosyal grupların aile ile oluştuğunu ifade etmektedir. Hz. Âdem, Hz. Havva ve çocuklarını bu bağlamda örnek gösteren Kur'an, sevgi, merhamet, iyilik, yardımlaşma, doğruluk ve Allah korkusunu izleyerek ailenin kuruluşunu önemsemiştir (Teyfurov, 2014, 243). İnsanlar sosyal bir varlık olmakla beraber bir ailenin üyesi olmaya ya da aile kurmaya hem psikolojik hem de fizyolojik açıdan muhtaç ve isteklidir. Bu bağlamda hem ferdin kendisi hem de toplum için önemli bir kurum olan aile, kişiyi yalnızlıktan uzak tutup ruhunu okşar. Esasen insan aile kurma niyetine eğilimli bir varlıktır. Aksi takdirde insanın hem gayrimeşru yollara hem de psikolojik sorunlara yönelmesi kaçınılmazdır. Dolayısıyla aile, gayrimeşru ilişki sonucunda meydana gelen pek çok psikososyal sorunlardan bireyleri uzak tutmaktadır. Bu sebeple İslâm’ da ailenin temel koşulu evliliktir. Kur'an, insanlara bu bağlamda sevgi, sayg1, muhabbet yönünde öğütler vermiş ve izlemesi gereken yolu sunmuştur (er-Rûm 30/21). Kur'an'da verilen bu yönlendirmeler ile planlı 
davranış teorisi bağlamında bireylerin bu doğrultuda olumlu yönde tutum sergilemeleri, evlilik yolundaki niyetlerine de olumlu yönde etki edecektir.

Kur'an aynı zamanda bireyin aile içerisindeki tutumlarına da dikkat çekmiştir. Ailede kar1-kocanın birbirleri ve her bir fert ile ilişkilerine, güvene, istikrara, hak, hukuk ve terbiyeye değinmiş; fitne ve fesada karşı da korunma mesajı içermiştir (et-Tegabün 64/14; el-Hucurât 49/13). Erkeğin kadına nasıl davranması ve birbirlerinin haklarına riayet etmeleri noktasında Kur'an, “Erkeklerin kadınlar üzerinde olan hakları olduğu gibi kadınların da erkekler üzerinde hakları vardır.", "Kadınlarınızla iyi geçinin. Onlardan hoşlanmayıp tiksinseniz; hoşlanmadığınız bir şeyde, Allah birçok hayır takdir etmiş olabilir" (en-Nisâ 4/4-19) şeklinde belirtmiştir. Aynı zamanda bireyin evlatlarına, evlatların da ebeveynlerine karşı sorumlulukları vardır. Kişi inançları gereği hangi konumda olursa olsun aile ilişkilerinde sorumluluklarını meydana getirme noktasında planlı davranış teorisine göre olumlu bir tutuma sahip olmalıdır. Anne-baba, evlatlarına iyi davranmalı ve kalplerini hoşnut kılmalıdırlar. Onları küçük düşürmemeli alaycı tavır sergilememeli, dini vazifelerini anlatmalı, dürüstlüğü tavsiye etmeli ve dolayısıyla onların ahlâk ve terbiyelerinde sorumluluk hissetmelidirler. Nitekim Kur'an'da “(Ey Resulüm!) ailene ve ümmetine namazı emret. Kendin de ona devam et." (Tâhâ 20/132) buyurulmuştur. Aynı zamanda evlatlar da anne ve babanın hakkını gözetmeli onlara itaat etmeli ve iyilikte bulunmalıdırlar (el-En'âm 6/151; el-İsrâ 17/23). Dolayısıyla insanın toplumsal ve bireysel sorumluluklarını en önemlisi dini vazifelerini gerçekleştirmesi açısından Kur'an'ın verdiği tavsiyeler doğrultusunda aileye dolayısıla evliliğe karşı olumlu bir tutum sergiler. Neticesinde evliliği gerçekleştirip aile kurma niyetini meydana getirme düşüncesini kuvvetlendirir. Aynı zamanda bireyin aile içindeki tutumlarına etki eden niyeti de şekillendirir. Ailesine karşı sorumlulukları bilir onlara iyi davranır ve haklarına riayet etme niyetinde olur. Kişi bu doğrultuda gitmediği takdirde doğacak sonuçları tahmin ettiğinden aksi davranışlara karşı olumsuz bir tutum sergiler ve kötü olanı ise gerçekleştirmeme eğiliminde olur.

\subsection{2. İyi Davranış / Kötü Davranış}

Kur'an'1 Kerim'de insan davranışlarına dair öğütler verilmekle beraber birçok olay da örnek gösterilmiştir. Bu bağlamda verilen örneklere ve yapılan ikazlara karşı insan davranışlarının sonuçlarını incelemek ve anlamak davranışa etki eden niyeti ortaya koymak açısından önemlidir.

Davranış, içeriden veya dışarıdan gelen etkilere, uyarıcılara karşı bir canlının şuurlu bir şekilde vermiş olduğu reaksiyonlardır (Kargiglioğlu, 2019, 12). İnsanlar, davranışlarının sonuçları ile ilgili önceden düşünür ve bir seçim yaparak sonuçlara ulaşmak için vardıkları kararları eyleme dönüştürür (Kağıtçıbaşı \& Cemalcılar, 2014, 141). İnsanların her biri birey olarak toplumun doğal bir üyesi olmakla beraber duygularını, yaşamını ve aynı mekânı paylaştığı, bireylerden meydana gelen toplumun kaçınılmaz bir üyesi konumundadır. Öyle

Journal of Analytic Divinity, https://dergipark.org.tr/tr/pub/jad Volume 5/1 
$\mathrm{ki}$, insanların bireysel davranışlarının ve fiillerinin sosyolojik, psikolojik ve dini sonuçları vardır. Din, kişinin davranışlarına, insanlarla olan etkileşimine dolayısıyla bireysel ve toplumsal yaşamına etki eden önemli bir unsurdur (Kafalı, 2005, 33). Bu bağlamda kişinin davranışları aynı zamanda düşüncelerinin arkasındaki ana unsur olan niyete, nasıl olması gerektiği konusunda ipucu vermektedir. Kişi dinden aldığı emirlerle hayatında asıl yapması gereken şeylerin ne olduğunu bilmekte ve niyetini o şekilde tasarlayıp, sergilemektedir. Bu da bireyin hür iradesini kullanarak esasen bireysel ya da topluma yönelik iyi veya kötü davranışını ortaya koymaktadır.

İnsanı diğer canlı ve varlıklardan farklı kılan doğal husus, onun kişilik sahibi olmasıdır. Kişilik, bireyin var olduğunun farkında olmasını, algı ve isteğiyle davranışlarına hâkim olmasını ifade eder. Varlığının bilinci içerisinde olan insan, çevresinde meydana gelen olayları ve olguları gözlemleme yeteneğine sahiptir. Bu yeteneği sayesinde insan, olguları maddi açıdan gözlemleyip belli sonuçlar elde etmekte ve kararlara ulaşabilmektedir. Kişi elde ettiği sonuçlar ve ulaştığı kararlar nispetinde ilke olarak davranışlarını serbest bir düzlemde gerçekleştirme özgürlüğüne sahiptir (Özgenç, 1996, 443). Kişinin sergilediği davranışların ardında saklı kalan niyet, iyi yönde bir davranış ya da kötü yönde bir davranış sergilemesine neden olur ki bu da insanın iradesiyle meydana gelir. Bu bağlamda özgür olan insan, gerçekleştirdiği davranışlarından ve daha da özünde niyetlerinden sorumludur.

Kur'ân'ı Kerimin birçok ayetinde insanların akıl sahibi ve doğruyu-yanlışı, iyiyikötüyü ayırt etme gücüne sahip olduğu ve sonucunda da kendi davranışlarını meydana getirdikleri (el-Mü'minûn 23/67; el-Enfâl 8/29) vurgulanmıştır. Bununla birlikte sürekli muhataplarına “Ey akıl sahipleri ya da akletmez misiniz?" gibi hitaplarda bulunmuştur (elMâide 5/100; el-Bakara 2/44).

İnsan yaradılış itibariyle iyiye ve kötüye karşı eğilimli olarak yaratılmıştır. Kur'an' da insana iyi ve kötünün gösterildiği “Ona iki yolu göstermedik mi?” (el-Beled 90/10) şeklinde ifade edilmiştir. Planlı davranış teorisinde davranışla ilgili düşüncelerin oluşması ve bu sonuçların değerlendirilmesi, olguların izah edilmesi ve neticesinde sahip olunan tutumun ortaya çıkması gibi Kur'an'ın bu ayetinde de Allah'ın insana bilgi edinme, düşünme, yargilama ve seçme yetenekleri verildiği, yetenekleriyle de insanın en seçkin varlık olarak yaratıldığı anlatılmaktadır (Karaman vd. 2017, 626). Ayetin devamında ise verilen uyarıları dikkate alıp iyi davranış sergileyenlerin, sergilemeyenlere karşı olumlu bir tutuma sahip olduklarını ve davranışa etki eden niyetlerinin iyilik yönünde olduğunu görmekteyiz (elBeled 90/11-18). Nitekim Şems suresinde geçen "Nefse ve onu şekillendirip düzenleyene; Ona kötü ve iyi olma kabiliyetlerini verene! Nefsini arındıran elbette kurtuluşa ermiştir. Onu arzularıyla baş başa bırakan da ziyan etmiştir." (eş-Şems 91/7-10) ayetlerinde vurgulanan kişinin nefsine, takva ve kötülüğün ilham edildiğidir. İnsana takvanın 
kötülükten daha üstün olduğu bildirilmiş ve nefsini günahlardan arındıran kişinin kurtuluşa ereceği, aksini gerçekleştireceklerin ise ziyana uğrayacağı söylenmiştir (Mahallî\& Süyûtî, 2016, 595). Dolayısıyla verilen uyarıları dikkate alacak kişi veya kişilerin davranışların sonucunu önceden düşünüp tahmin etmeleri ve bu bağlamda takvaya karşı olumlu bir tutum, kötülüğe ise olumsuz bir tutum içinde olmaları beklenir. Nihayetinde verilen bu ayetler ışı̆̆ında tutumların etki ettiği niyetleri açıklamak mümkündür.

$\mathrm{Bu}$ durumun teşkil ettiği bir başka örneği kavimlerde görmek mümkündür. Kur'an'da, bütün kavimlere bir uyarıcının gönderildiği ve doğru yola davet metotlarının peygamberler aracılığı ile gerçekleştirildiği; kavimlerin kendi dilleri ile uyarıldığı, tebliğ görevini yerine getirip tevhid için mücadele edildiği bilinmektedir (el-A'râf 7/6; İbrâhîm 14/4; el-En'âm 6/163). Nitekim peygamberlere inananlar, davranışlarının doğuracağ1 sonuçları düşünüp doğru yolda ilerlemek adına peygamberlerin ardından gitme niyetini oluşturmuş ve davranışlarını sergilemişlerdir. İnanmayanlar ise helak olmuşlardır. Bu bağlamda Kur'an'da geçen Nûh kıssası bu duruma örnek teşkil etmektedir. Hz. Nûh ve ona inananlar kurtulurken eşi, oğlu ve diğer inanmayanlar boğulmuşlardır (Hûd 11/40-47; elMü'minûn 23/26-29; el-Furkan 25/37; el-Kamer 54/10-17). Netice şudur ki uyarılara karş1 inananlar, inanmayanlara göre olumlu bir tutum oluşturmuş ve niyetlerini doğru olduğunu düşündükleri tevhid inancıyla Hz. Nûh'a katılma davranışlarıyla sergilemişlerdir.

Kur'an'da niyete etki eden ahlaki tutumların belirtildiği bir diğer konuların şu şekilde sıralanması mümkündür:

- Alay edip küçültücü lakaplar kullanmak (el-Hucurât 49/11).

- Adaletli olmak ve alçak gönüllülük (el-Mâide 5/8; el-Hac 22/34).

- Cimrilik ve israfçılık (el-İsrâ 17/26-27; el-Hümeze 104/2-6).

- Bağışlanmayı istemek, şükretmek (Hûd 11 /3; ez-Zümer 39/66).

- Mal ve çoklukla övünmek (et-Tekâsür 102/1).

- Faiz yememek (Âl-i İmrân 3/130).

- Mazlumları, zayifları korumak (en-Nisâ 4/75)

- Sorumluluklarını (ibadet) bilmek (namaz kılmak, oruç tutmak, zekât vermek...) (elBakara 2/43-183).

İnsanın oluşturduğu iyi veya kötü davranışlarda niyet asıldır. Yolda olan bir taşın kaldırılması, toplumun sağlı̆̆ının düşünülmesi, tebessüm edilmesi, yetimin başının okşanması gibi küçük bir davranışın sonuçlarını sırf Allah rızasını düşünerek gerçekleştirmek kişinin olumlu bir tutum içinde olmasını sağlar. Kişi aksini düşündüğünde (faiz yemek, zulmetmek, yetimin hakkını yemek vs.) ise olumsuz bir tutuma sahip olmakla beraber o davranışı oluşturma eğiliminin düşük olmasına neden olur. Dolayısıyla Kur'an'daki olay ve hadiselerdeki insan davranışları (iyi-kötü), tutumları ve tutumlar üzerine yapılan davranışların sonuçlarıyla ilgili olası düşüncelerin değerlendirilmesi gibi olgulardan etkilenip davranışlarını, tutumların oluşturduğu niyetler sonucunda sergiler.

Journal of Analytic Divinity, https://dergipark.org.tr/tr/pub/jad Volume 5/1 


\subsubsection{Niyet-İhlas Etkileşimi}

Müslüman bir kişinin Allah'ın rızasını kazanma noktasında ihlas içinde, ibadeti ve düşünceleri kötülüklerden ve ikiyüzlülükten arındırarak duruluk, içten bağl1lıkla Allah dışındaki her şeyden uzak bir tutum sergilemesi beklenir (Isfahânî, 2010, 354). İhlas, ahlâki çerçevede bireyin, erdemlilik sürecine daha doğrusu gerçek anlamda insan olma yoluna girişinin ilk temel koşulu niteliğinde olması nedeniyle büyük bir önem ve değere sahiptir.

Bireyin kurtuluşu yolundaki esas faktörlerden biri olan ihlas, Kur'an'da muhlis, muhlas, muhlism, muhlasm, ed-dinu'l halis gibi kısımlarıla da mevcut olmakla beraber niyet ile bağlantılı olup niyetin sıhhati ve sağlamlığı konusu ile alakadardır (Ekin, 2002, 148). İhlas, niyet kavramının önemli temel taşlarından birini teşkil etmektedir. Kişinin hal ve hareketlerinde aynı zamanda duygu ve düşüncelerinde ihlası barındırmak niyetin taviz vermediği unsurlardan olduğu gibi işleri de güzelleştirir. İhlas; İnsanın doğru ya da yanlış davranışlarını veyahut tutumlarının oluşturduğu iyi veya kötü niyetlerin açık veya gizli olanını ortaya koyabilmede önemli bir role sahiptir. Kur'an ise bunu “De ki, gönlünüzdeki duyguları saklasanız da açıklasanız da Allah hepsini bilir." (Âl-i İmrân 3/29) ayeti ile desteklemektedir. Yani davranışların, eyleme dönüştürülmemiş düşüncelerin veya söylemlerin arkasındaki asıl nedenin dolayısıyla niyetin doğruluğunu veya yanlışlığını açık olanının da gizlisinin de bilindiği belirtilmiştir. Ayette böyle geçmesine rağmen planlı davranış teorisine göre insanların bu doğrultudaki tutumlarının olumlu veya olumsuz olması yine niyetlerine etki etmektedir. Bu doğrultuda Kalem suresi 17-33. ayetlerde anlatılmış olan bahçe sahipleri kıssasında, bahçe sahiplerinin, infaktan yararlanacak kişileri bu durumdan habersiz birakıp onları mahrum bırakmak istemeleri ve kendi planları ile sabah erkenden bahçeye gittiklerinde kendi mahsullerinin ziyana uğradı̆̆ını görmeleri de kendilerinin gizlice planladıkları niyetin karşılığı olmuştur (Cora, 2020, 212). Dolayısıyla Kur'an'da verilen mesajlara karşı olumlu ya da olumsuz bir tutum içinde olmak bireyin, doğrudan davranışını oluşturan niyetine etki etmektedir.

\section{Kur'an'da Algılanan Sosyal Baskı ve Niyet}

Bir insanın, başka insanlar tarafından kendi davranışları hakkında ne düşüneceği, nasıl tepki vereceği ile ilgili inançları ve insanın bu beklentilere ne ölçüde uyacağı niyeti etkiler (Kağıtçıbaşı \& Cemalcılar, 2014, 141). Bir başka tanıma göre planlı davranış teorisinde yer alan sosyal baskı, düşünülen bir davranışı gerçekleştirmek veya gerçekleştirmemek ya da insanın önemsediği kişilerin, yapacağı davranışları onaylayıp, onaylamamasıdır (Yay \& Çalışkan, 2016, 111). İnsanlarda olumlu ya da olumsuz etki 
oluşmasına sebep sosyal çevre; aile bireyleri, akranları, öğretmenleri, rol modelleri denilebilir. Bu durum dini açıdan ele alınacak olursa, verilen etmenlerin yanında bir de peygamberler, sahabeler, evliyalar veyahut din adamları olabilir. Planlı davranış teorisi bağlamında kişiler, bu rol modellerin görüş ve düşüncelerine uygun olan davranışlar sergilemek isterken, bunun yanında rol modellerin uygun karşılamadığ 1 davranışlardan ise kaçınırlar (Göktürk, 2019, 28).

İnsanların içinde yaşamış oldukları toplumun gelenek, görenek ve adetleri, baskı ve kuralları doğrultusunda kabul gören değerlerdir. Algılanan sosyal baskı, diğer bir ifadeyle kişisel normlar insanların kendi yollarını seçme doğrultusunda bireylere kılavuz olmaktadır. İnsanın kendisi, olumlu tutuma sahip olmakla birlikte diğer insanlarda oluşan olumlu tutumu da etkilemektedir. Kişilerin önemsedikleri, ne düşündüklerini merak ettikleri ve değer verdikleri insanların görüşlerini kapsayan algılanan sosyal baskı, insanların dini eğilimlerine etki etmektedir (Bozkurt, 2014, 31). Kişiler, sosyal baskıyı öncelikli olarak toplumun temelindeki ilk yapı taşı olan ailelerinde hisseder. Ailenin dini tutum, düşünce ve görüşleri kişiler için önemlidir. Örneğin, faizli kredi çekmeyi düşünen bir kişinin, ailesinin bu konudaki yani krediyi çekme davranışını onaylayıp onaylamayacağına ilişkin görüşü, o davranışı yapmaya ya da yapmamaya niyet etmesinin belirleyici unsurudur. Aynı zamanda kişinin içinde yaşadı̆̆ 1 toplum, kültür, coğrafyanın dini değerleri ve görüşleri de kişi için önemli olup kişinin davranışını oluşturmasında niyetini etkiler.

\subsection{Sosyal Baskıya Etki Eden Örf-Adet ve Gelenekler}

Sosyal bir varlık olan insan, çevresi ile etkileşim halindedir. Kişilerin dini birikimleri ve tercihleri sosyalleşmenin temel taşını oluşturmakla beraber davranışlarına yönelik süreçleri bünyesinde barındırır (Güngör, 2012, 86). Dini açıdan kişi, davranışlarını gerçekleştirmeden önce etkileşim halinde olduğu çevredeki rol modellerin o davranış hakkındaki düşüncelerinin olumlu ya da olumsuz yönde olup olmadığını düşünerek, kendisine verilecek tepkilere göre hareket eder. Bireyin, davranışını oluşturmadan önce toplumun yazısız kuralları olan örf-adet ve geleneklerine yönelik ön kabulleri kişinin davranışını gerçekleştirme niyetine etki eder.

Kur'an' da, eski cahiliye Araplarına bakıldığında kabilecilik yaşamı ile birlikte putlara tapan, panayırlar düzenleyen, içki içen, kız çocuklarından utanç duyan, doğru olmayan çeşitli adet ve gelenekleri olan bir toplum olduğu görülmektedir (eş-Şuarâ 42/13; el-Bakara 2/219; et-Tekvir 81/8-9; el-Ahzâb 33/33). Hz. Peygamber' in İslam daveti onlara gittiğinde bir kısmı kabul etse de büyük bir kısmı atalarının veya içerisinde bulundukları çevrenin kendilerini aşağılayıp, dışlayacaklarını düşündüklerinden dolayı inanmamışlardır. Daveti kabul edip İslam'a girenler ise bu adetleri terk ederek Hz. Peygamber'in söyledikleri doğrultusunda yaşamaya başlamışlardır. Yaptıkları her davranış öncesinde dinin bu

Journal of Analytic Divinity, https://dergipark.org.tr/tr/pub/jad Volume 5/1 
konuya bakış açısı bununla doğru orantılı olarak Hz. Peygamber' in bu davranışlara olan tepkisi niyetlerine ve niyetin eyleme dönüşmesini belirlemiştir. Dolayısıyla algılanan sosyal baskı kişilerin davranışı gerçekleştirmedeki niyetine eki etmiştir.

Kur'an, insanlara (cahiliye Araplarına) doğruları bildirmesine rağmen; onlar, atalarının, saygı duydukları ve önemsedikleri davranış ve düşüncelerini benimsemiş, o yolu takip etmeyi seçmişlerdir (es-Sâffât 37/69-70). Bu durum yine aynı şekilde Bakara suresinde, onların körü körüne bağlanmalarına, doğruyu inkâr etmelerine ve atalarını taklit etmelerine karşılık şaşkınlık ifade edilmiştir (el-Bakara 2/170). Aynı ayet üzerinden Kur' an, cahillerin atalar geleneğine olan bağlılıklarını ve onları yüceltmelerini sorgulamış; zihinlerini işleme geçirmelerini istemiştir (Sâbûnî, 1986, 114).

Kur'an'ın bu uyarılarına rağmen inkârcılar, atalar geleneğini yüceltmiş ve o yönde gitmenin en kutsal davranış şekli olduğu savunulmuştur. Çünkü onlara göre, yıllarca gerçekleşen dini törenler, inanışlar yanlış olmuş olsaydı atalar bunu bilir ve terk eder, kendilerine de miras bırakmazdı. Bu duruma Kur'an, ne onların ne de atalarının bir bilgisi olmadığını söylediklerinin çirkin ve yalan olduğunu ifade etmiştir (el-Kehf 18/5). Bu bağlamda cahiliye toplumları atalarından aldıkları, duydukları her şeyi kesin doğru kabul etmiş, koşulsuz bağlanmışlardır. Öyle ki, kendilerine doğru olan (vahiy) geldiğinde bile kabul etmemiş ve onlara (atalara) olan sayg1 ve bağlılık buna engel olmuştur (Yıldız, 2015, 192-194). Dolayısıyla cahiliye Arapları algılanan sosyal baskı (atalar geleneği) nedeniyle kendilerinin doğru yolda olduğuna ve bu doğrultuda ilerlemeleri gerektiğine inanarak davranışlarını gerçekleştirme niyetlerine tabi olmuşlardır. Bununla birlikte vahyi de inkâr ederek yani atalarının bu durumu onaylamayacağını düşünerek bu doğrultuda davranış geliştirmeme eğilimi içinde olmuşlardır.

\section{Kur'an Bağlamında Algılanan Davranışsal Kontrol ve Niyet}

Ajzen'e göre, algılanan davranışsal kontrol, kişilerin bazı davranışlarının diğer davranışlarından daha fazla kontrol altında olduğu ve önemli olanın kişinin kontrolle ilgili düşünceleridir (Kağıtçıbaşı \& Cemalcılar, 2014, 141). Planlı davranış teorisinde önemli bir rol üstlenen algılanan davranışsal kontrol, kişinin bir davranışının zor ya da kolay olması ile ilgili inancını açıklamakta ve her durumda olmamakla birlikte davranışa direkt etki etmektedir (Yüzüak, 2017, 18). Algılanan davranışsal kontrol, genellikle durumlara ve eylemlere göre değişme gösterebilir (Ajzen, 1991, 183). Kişi bir davranışın ortaya çıkmasına yönelik imkân ve fırsatların var olduğuna ne kadar fazla inanırsa kişinin o davranış üzerinde algılanan davranışsal kontrolünün inandığı ölçüde fazla olması beklenir (Öztürk vd. 2015, 147). Bu doğrultuda kontrol inançları iki şekilde etki etmektedir: 
1. Algılanan davranış zorlukları: Bireyin bir davranışı meydan getirme sürecinde karşılaşmış olduğu ya da karşılaşacağını düşündüğü zorluklar.

2. Algılanan davranış kolaylıkları: Bireyin bir davranışı meydan getirme sürecinde karşılaşmış olduğu ya da karşılaşacağını düşündüğü kolaylıklar (Kılıç, 2018, 13).

Kişilerin dini değerleri, sorumlulukları ve inançları da kişinin davranışlarının oluşumunda kolaylık ya da zorluk durumundan etkilenip kendi yeterlilikleri ve etkileri sonucunda belirleyici rol oynayabilmekte veya oynayamamaktadır.

\section{1. Ödül-Ceza}

Kur'an'da insanın yapması veya yapmaması gerekenler doğrultusunda belli başlı kurallar vardır. Bu kurallar kişiye özgür davranışlar sunarken aynı zamanda bireyin bazı konularda davranışlarını sınırlaması gerekmektedir. Bu bağlamda kurallara tabi olan kişiler mutlu olur, refaha erer ve ödüllendirilir; fakat uymayanlar ise kınanır, sertçe eleştirilir veya cezalandırılır (el-Zilzâl 98/7-8; Âl-i İmrân 3/200; en-Nahl 16/93-97). Kişi, irade yönünden hür, sergilediği davranış, eylem veya işlerinde yani bunları planladığı niyetler yönünden ise sorumlu bir varlıktır. Bu doğrultuda:

\subsection{1. İrade ve Sorumluluk}

Kişinin davranışlarındaki herhangi bir niyeti oluşturan koşulların mevcut olması, doğal bir durum teşkil etmektedir. Ortaya çıkan irade, istek ve ihtiyaç doğuran nitelikler içerisinde bir uygunluk var olmaktadır (Çetintaş, 2014, 55). Kur'an, sorumluluğun üzerinde önemle durmuş ve aynı zamanda bireylerin kendi iradeleri ile sergiledikleri davranışlar noktasında uyarmış ve yapılması gerekenlerden söz etmiştir. Planlı davranış teorisinde yer alan davranışsal kontrol bağlamında Kur'an, insanların hac ibadetini yaya olarak veya develer üzerinde dahi olsa yapmaları gerektiğinden bahsetmiştir (el-Hac 22/27). Bu durum, günümüz koşulları ile ilişkilendirildiğinde kişinin, yapılması gereken asıl davranışın kendi kontrolü altında olmadığına inanmasıdır. Hacca gitme sorumluluğunda "durumum yok" şeklinde kendini ifade etmesi, imkânının el vermediğini bildirmesi ya da hasta olması kişinin performansını düşürür. Bunu yapacak güce inanmış ve niyetlenmiş olsa dahi dinin ve kendisinin beklentilerini yerine getirme çabası fayda vermeyecektir. Bu konu aynı zamanda kişinin iradesi dışında bir durum teşkil ettiğinden sorumluluğunu ortadan kaldırır. Yapmaya imkânı olan ve bu davranışı gerçekleştirmeye inananların davranışı sergiledikten sonra dini sorumlulukları yerine getirdiklerinden bu kişiler ödüllendirileceklerdir.

Bakara suresinde "Namazı dosdoğru kılın, zekâtı verin ve rükû edenlerle birlikte siz de rükû edin.” (el-Bakara 2/43) şeklinde geçen ayet için de söylemek mümkündür. Şöyle ki, kişi zekâtı verme konusunda olumlu bir tutuma sahip olabilir, aynı zamanda çevresindekilerin ve dinin bu düşünceyi onayladığını düşünebilir. Ancak zekâtı verecek parası veya herhangi bir mal varlığı yoksa kişinin tutumu davranışının belirleyicisi olamaz

Journal of Analytic Divinity, https://dergipark.org.tr/tr/pub/jad Volume 5/1 
ve kişi için zor bir durum söz konusudur. Dolayısıyla kişinin tutumuna dayanarak davranışını açıklamak veya bir çıkarımda bulunmak doğru sayılmaz. Aynı zamanda söz konusu sağlıklı bir şekilde ayakta namaz kılıp rükû etme konusunda olumlu tutuma sahip birisi içinde geçerlidir. Kişi sağlık sorunları nedeniyle yatalak olmuş ve bu durumu tam olarak yerine getiremiyorsa yine o kişinin tutumu davranışlarının belirleyicisi olamamaktadir.

Verilen ayetlerin (el-Hac 22/27; el-Bakara 2/43) neticesinde kişinin hacca gitmeye, zekât vermeye, yetimi doyurmaya, sadaka vermeye (el-İnsân 76/8) karşı olumlu bir tutum içerisinde olması, çevrenin ve dinin olumlu düşüncelerini gerçekleştirebilme niyetine ehil olması yanında en önemlisi kişinin bunları yapabileceğine inanması ve fırsatlarının bulunmasıdır. Kişinin performansına kolaylaştırıcı mevcut etkenler bulunduğundan, fayda içerdiğinden, kişisel normlarla örtüştügüunden ve inancı yüksek olduğundan niyetlerin etki ettiği davranışları sergilemesi yüksektir.

Algılanan davranışsal kontrolü doğrudan açıklayabilirliği durumunda Kur'an'da “Gündüzün güneşin gün ortasını aşmasından gecenin karanlığına kadar namazını kıl; bir de sabah namazını; çünkü sabah namazı şahitlidir" (el-İsrâ 17/78) şeklinde geçen bu ayette beş vakit namaz ve o namazların hangi zaman dilimlerinde kılınması gerektiğinden bahsedilmektedir (Yazır, 1993, 410). Ayette geçen "bir de sabah namazını kıl” cümlesi ele alındığında örneğin, iki kişiden bu sorumluluğu başaracağına ve sabah namazı vaktinde uykusundan uyanıp sabah namazını kılacağına olan güveni ve inancı yani yapılabilirlik algısı yüksek olan kişi, uyanamayacağını düşünen, şüphesi olan kişiye kıyasla daha emin uyanmaya çalışır. Dolayısıyla bu konuda daha başarılı olması beklenir. Kişi iradesi neticesinde sorumluluğu yerine getirdiği için mükâfatını alır, getirmeyen başaramayan kişi ise cezalandirilır.

Algılanan davranışsal kontrol kişinin kendi kontrolü ile ilgili bir durum teşkil etmekte olup zorlaştırıcı ve kolaylaştırıcı etmenler karşısında, kişinin davranışı sergileme inancını konu edinirken Kur'an bazında incelendiğinde de algılanan davranışsal kontrol etmenlerinin ilişkilendirildiği ve benzerlik içerdiği görülmektedir.

\section{Sonuç}

İnsan davranışlarının oluşumunda temel etkenin ne olduğu hususunda birçok iddia öne sürülmüş ve teoriler geliştirilmiştir. Bu teorilerden biri olan planlı davranış teorisinde, insan davranışlarının oluşumunda en etkili rol oynayan ana unsurun niyet olduğu sonucuna varılmıştır. Bununla beraber niyete etki eden etmenlerin de üç faktörden oluştuğu belirtilir. Bunlar; "davranışa yönelik tutum", "algılanan sosyal baskı" ve "algılanan davranışsal kontrol" dür. Planlı davranış teorisinde açıklanan niyet ve İslam 
düşünce geleneğindeki niyet kavramı benzerlik içermekte olup, İslam dinindeki niyetin tanımı: Allah'ın istediği davranışa yönelen irade ve buna bağlı olarak bir şeyi gerçekleştirmeyi istemektir. Planlı davranış teorisinde ise niyet, meydana gelen davranışın ardındaki asıl etkendir. Dolayısıyla kişiler meydana getirdikleri birçok davranışı belirli nedenler doğrultusunda oluşturmaktadır.

İnsanlar, davranışlarını meydana getirmeden önce o davranışa karşı olumlu ya da olumsuz yönde birtakım yargılara sahip olmaktadır. Bu düşünce ile tutum kavramı ifade edilmektedir. Bu tutumların niyete etki ettiği ve sergilenen davranışların da niyet bağlamında ortaya çıktığı görülmüştür. İnsanların, yaşamında tutumlarına etki eden birçok etken mevcuttur. $\mathrm{Bu}$ etkenlerden bir tanesi inanışların temelini oluşturan dindir. $\mathrm{Bu}$ bağlamda İslam dinine mensup kişilerin davranışa yönelik tutumlarında en önemli unsur Kur'an' dır. İnsanın hem bireysel hem de toplumsal hayatına yönelik, içerisinde birçok konu barındıran Kur'an, insanda oluşan tutumlar yönünde ahlâka geniş bir yer vermiştir. Planlı davranış teorisi ile bu durum ele andığında, insanın zamanla rol modeli değişmekte olup olumlu ya da olumsuz yönde tutumunu ilk olarak toplumun temel yapı taşı olan ailesinden almaktadır. Planlı davranış teorisi bağlamında Kur'an'ın bu konuda verdiği tavsiyelerde Müslüman bir kişinin, aileye, evliliğe karşı olumlu; ahlâk dışı eylemlere yol açan davranışlara ise olumsuz bir tutum içinde olması gerekir. Kişinin bireysel veya topluma yönelik ahlâkı üzerindeki olumlu veya olumsuz tutumları, niyetlerini dolayısıyla davranışlarını oluşturması veya oluşturmaması yönündeki kararlarını doğrudan etkilemiştir. Planlı davranış teorisi bağlamında Kur'an' da üzerinde durulan bir diğer konu olan ihlas, insan davranışlarının iyi ya da kötü niyetler sonucunda oluştuğunu ve Kur'an' da da gönüllerde olanın, gizlisinin de açık olanının da bilindiği ifade edilir. Buna rağmen insanların bu yöndeki tutumlarının olumlu veya olumsuz olması davranışlarını oluşturan niyetlere etki etmiştir. İnsanın davranışlarının ardındaki niyetlere etki eden algılanan sosyal baskı ise düşünülen bir davranışın gerçekleştirilmesi veya gerçekleştirilmemesinde, insanın önemsediği kişilerin, yapacağı davranışları onaylayıp onaylamaması durumuna bağlı olmaktadır. İnsanların, içinde yaşamış oldukları toplumun gelenek, görenek ve adetleri, sosyal baskıya etki etmiştir. Kur'an bağlamında örnek bir bakış olarak cahiliye toplumu gösterilebilir. Algılanan sosyal baskıyı temsil eden atalar geleneğine bakıldığında kişilerin, eski inanışları ve atalarına olan bağlılıkları sebebiyle davranışlarına yön verdikleri görülmüştür. Öyle ki, algılanan sosyal baskının, tarih öncesinden günümüze kadar yapılan çalışmalarda, niyet üzerinde etkili olduğu sonucuna ulaşılmıştır. İnsanlar, sosyal hayatlarında bir davranışı gerçekleştirmeden önce çevre faktörünün (aile, arkadaş, din adamları vs.) olumlu-olumsuz (ne derler?) tepkileri doğrultusunda davranış gerçekleştirmiştir.

Kişilerin bir davranışın zor ya da kolay olması ile ilgili inancını açıklayan algılanan davranışsal kontrol, niyete etki eden diğer iki unsurdan farklı olarak, her durumda geçerli olmayıp davranışa doğrudan etki etmiştir. Asıl olanın, kişinin bir davranışının ortaya çıkmasına yönelik imkân ve fırsatlarının var olduğuna ne derece inanıp-inanmaması

Journal of Analytic Divinity, https://dergipark.org.tr/tr/pub/jad Volume 5/1 
durumu ile ilişkili olduğu görülmüştür. Dolayısıyla kişi, ne kadar fazla inanırsa, davranış üzerindeki algılanan davranışsal kontrolü o derece fazla olur ve davranışı gerçekleştirme ihtimali artar. Bireyin inanç seviyesi düşük ise algılanan davranışsal kontrol de düşük olmakla beraber davranışı gerçekleştirme eğilimi de o derece düşük olur. İnsanın davranışlarında etkili olan dine bakıldığında, imkânların ve fırsatların fazla olduğunu düşünen bireyler için dini davranışlarını oluşturmada etkili bir unsur olduğu görülmüştür. Günümüzde de bu durum göz önünde bulundurulduğunda hacca gitmek isteyen bir birey sadece istekle bu davranışı gerçekleştiremeyeceğinin farkında olup kendisinin iyi bir maddi imkâna sahip olması gerektiğinin bilincindedir. Maddi imkânının yeterli olmadığı düşüncesi davranışını gerçekleştirme ihtimalinin düşük olması sonucuna; maddi yeterliliğin olduğu inancı ise davranışı gerçekleştirme ihtimalinin yüksek olduğu sonucuna ulaştırmıştır. Kişilerin dini değerleri de davranışlarının oluşumunda kolaylık ya da zorluk durumundan etkilenip kendi yeterlilikleri sonucunda belirleyici rol oynamaktadır. Dolayısıyla kişinin sadece tutumu göz önünde bulundurularak davranışını açıklamak veya davranışından bir çıkarımda bulunmak yeterli olmamıştır.

\section{Kaynakça}

Ajzen, Icek. "The Theory of Planned Behavior". Organizatıonal Behavior And Human Decısıon Processes 50 (1991), 179-211.

Ajzen, Icek. "Constructing a TpB Questionnaire: Conceptual and Methodological Considerations".(2006)http://www.people.umass.edu/aizen/pdf/tbp.measuremen t.pdf, (Erişim Tarihi: 12.01.2021).

Ajzen-Icek, Fishbein-Martin. “The İnfuluence Of Attitudes Of Behavior”. The Handbook Of Attitudes (2005), 173-221.

Belçika Diyanet Vakfı. 28 Kasım 2020 "İslam Ahlâkı". https://www.diyanet.be/DiniBilgiler/\%C4\%B0slam-Ahlak\%C4\%B1

Bozkurt Kutluk-Avcıkurt, Ayşegül -Cevdet. "Planlanmış Davranış Teorisi ile Yerli Y Kuşağı Turistlerin Destinasyon Tercih Etme Niyetlerinin Belirlenmsi". Afyon Kocatepe Üniversitesi Sosyal Bilimler Dergisi 21/4 (2019), 1294-1307.

Cora, Mustafa. "Kur'an Muhtevası Açısından Niyet ve Önemi". Kesit Akademi Dergisi 6/23 (2020), 198-236. 
Çetintaş, İbrahim. “Niyet Kavramı Bağlamında Fiillerin Hakikat Değeri”. Süleyman Demirel Üniversitesi İlahiyat Fakültesi Dergisi 32/1 (2014), 51-70.

Dönmez, İbrahim Kâfi. "Niyet". Türkiye Diyanet Vakfi İslam Ansiklopedisi. 33/169-172. İstanbul: TDV Yayınları, 2007.

Ekin, Yunus. "İhlas Kavramının Semantik Analizi". Tasavvuf İlmi ve Akademik Araştırma Dergisi 9 (2002), 147-160.

Erten, Sinan. "Planlanmış Davranış Teorisi ile Uygulamalı Öğretim Metodu". Hacettepe Üniversitesi Edebiyat Fakültesi 19/2 (2002), 217-233.

Gazâli. İhyâu Ulûmi'd-Dîn. Çev. Ahmet Serdaroğlu. 4 cilt. İstanbul: Bedir Yayınları, 1987.

Göktürk, Emre Tunahan. Tüketicilerin Helal Ürün Satın Alma Tutumlarının İncelenmesi: Planlı Davranış Teorisi Bağlamında Pilot Bir Araştırma. İstanbul: Marmara Üniversitesi Sosyal Bilimler Enstitüsü İşletme Anabilim Dalı, Pazarlama Bilim Dalı, Yüksek Lisans Tezi, 2019.

Gündüz, Muhammed Muhdi. "Niyet Kavramı ve Din Eğitimi Açısından Anlam Katmanları". Siirt Üniversitesi İlahiyat Fakültesi Dergisi 6/2 (2019), 301-332.

Güngör, Özcan. "1. 5 ve 2. Nesil Türk Gençlerinin Ailede Dini Sosyalleşmeleri: New Jersey, USA Örneği". Ankara Üniversitesi İlahiyat Fakültesi Dergisi 53/2 (2012), 85-119.

Güngör, Özcan. İki Dünya Bir Aile. Ankara: Akçă̆ Yayınları, 2016.

Güngör-Özcan, Şahin-Harun. "Sosyolojik Kur'an Okumalarının İmkânı". Uluslararası Sosyal ve Beşeri Bilimler Dergisi 1/1 (2017), 26-37.

Isfahânî, Ragıp. El-Müfredat Fi Garibi'l Kur'an (Kur'an Kavramları Sözlüğ̈̈̈). Çev. Abdulbaki Güneş, Mehmet Yolcu, İstanbul: Çıra Yayınları, 2010.

Kafalı, Hasan. Lisans Öğrencilerinde Dini İnanç ve Tutumlarn Sosyal İlişkilere Etkisi Ergani Örneği. Konya: Selçuk Üniversitesi, Sosyal Bilimler Enstitüsü Felsefe ve Din Bilimleri Anabilim dalı Din Sosyolojisi Bilim Dalı, Yüksek Lisans Tezi, 2005.

Kağıtçıbaşı-Çiğdem, Cemalcılar-Zeynep. Dünden Bugüne INSAN ve INSANLAR Sosyal Psikolojiye Giriş. İstanbul: Evrim Yayınevi, 2014. 
Karahan, Mehmet Ozan. Dijital Korsanlıkta Planlı Davranıs Teorisi ve Etik Kavramının Etkisi. Kütahya: Dumlupınar Üniversitesi Sosyal Bilimler Enstitüsü İşletme Anabilim Dalı, Doktora Tezi, 2018.

Karaman, Hayrettin. vd. Kur'an-ı Kerim Meali. İstanbul: Diyanet İşleri Başkanlığı Yayınları, 2017.

Karaman, Hayrettin. vd. Kur'an Yolu Türkçe Meal ve Tefsiri. 5 cilt. Ankara: Diyanet İşleri Başkanlığı Yayınları, 2017.

Kargiglioğlu, Şaban. Planlı Davranış Teorisi Bağlamında Sokak Lezzetlerinin Destinasyon Seçimi ve Tekrar Ziyaret Etme Niyetine Etkisi: İstanbul İli Örneği. Ankara: Gazi Üniversitesi Sosyal Bilimler Enstitüsü, Doktora Tezi, 2019.

Kılıç, Mahmut Sami. Planlanmış Davranış Teorisi Yoluyla Öğretmen ve Öğretmen Adaylarının Fen Bilimleri Dersi Kapsamında Laboratuvar Uygulamalarmı Gerçekleştirmeye Yönelik Davranış Amaçlarının Belirlenmesi. Kastamonu: Kastamonu Üniversitesi Fen Bilimleri Enstitüsü İlköğretim Anabilim Dalı, Doktora Tezi, 2018.

Kocagöz-Elif, Dursun-Yunus. “Algılanan Davranışsal Kontrol, Ajzen`in Teorisinde Nasıl Konumlanır? Alternatif Model Analizleri". KMÜ Sosyal ve Ekonomik Araştırmalar Dergisi 12 /19 (2010), 139-152.

Koç, Erdoğan. Tüketici Davranışı ve Pazarlama Stratejileri. Ankara: Seçkin Yayınları, 2013.

Küçük, Ergün. "Planlanmış Davranış Teorisi Çerçevesinde Mali Müşavir (SMMM) Olma Niyetinin Altında Yatan Faktörlerin Analizi". ZKÜ Sosyal Bilimler Dergisi 7/14 (2011), 145-162.

Özgenç, İzzet. "Davranış Normları Teorisi (Haksızlık ve Müeyyide İlişkisi)". Selçuk Üniversitesi Hukuk Fakültesi Dergisi 5/1-2 (1996), 443-454.

Öztürk, Abdulkadir. vd. "Tüketicilerin Helal Tüketim Davranışlarının Belirleyicileri: Planlı Davranış Teorisi Çerçevesinde Bir Araştırma". Uluslararası İslam Ekonomisi ve Finansı Araştırmaları Dergisi 1/2 (2015), 141-160.

Sâbûnî, Muhammed Ali. Safvetü't Tefasir. 3 cilt. Beyrut: Dâru'l Kalem, 1986.

Sandıkçı, Kemal. Hadisler Işı̆̆ı̆nda İslam. 2 cilt. İstanbul: Ensar Neşriyat, 2018. 
Şavlı, Medeni. "Literatürde Meşhur Olan Niyet Hadisinin İslam Hukuku Açısından Ehemmiyeti". Yüzüncü Yıl Üniversitesi Sosyal Bilimler Enstitüsü Dergisi 42 (2018), 305320 .

Subaşı, Necdet. “Din ve Toplum”. İstanbul Üniversitesi Açık ve Uzaktan Eğitim Fakültesi Sosyoloji Lisans Programi, Ankara, 2014.

Mahallî-Celâleddin, Süyûtî-Celâleddin. Tefsirül'l-Celaleyn. Diyarbakır: Seyda Yayınları, 2016.

Mercan, Nuray. "Ajzen'in Planlanmış Davranış Teorisi Bağlamında Whistleblowing (Bilgi İfşası)". Sosyal ve Beşeri Bilimleri Dergisi 7/2 (2015), 1-14.

Tekkaya, Ceren. "Geri Dönüşüm Davranışının Planlanmış Davranış Teorisi İle Açılanması: Sürdürülebilir Bir Kampüs İçin Geri Dönüşüm Anketi". 2nd İnternational Conference on New Trends in Education and Their Implications (Antalya), Ankara: Siyasal Kitabevi, 2011.

Teyfurov, Mansur. "Kur'an-1 Kerim'de Aile Yapısı". I Ĭgdır Üniversitesi İlahiyat Fakültesi Dergisi 3/4 (2014), 241-258.

Türker, Ömer. vd. Dinî ve Felsefî Düşüncede Niyet Kavramı. Ankara: İlem Kitaplığı Yayınevi, 2017.

Türk Dil Kurumu Sözlükleri. 20 Aralık 2020. https:/ sozluk.gov.tr/

Türkmen, Serkan. Tüketici Etnosentrizminin ve Destinasyon Kişiliğinin Yerli Turistlerin Paket Tur Satın Alma Niyetleri Üzerindeki Etkisinin Belirlenmesi. Balıkesir: Balıkesir Üniversitesi Sosyal Bilimler Enstitüsü Turizm İşletmeciliği ve Otelcilik Anabilim Dalı, Doktora Tezi, 2015.

Vatandaş, Celalettin. “Sosyolojinin Konusu Olarak Ahlâk”. Eskiyeni Dergisi 20 (2011), 6672.

Yay-Özlem, Çalışkan-Osman. "Planlı Davranış Teorisi Bağlamında Çevreci Otel Restoranında Yemek Yeme Niyeti". Seyahat ve Otel İşletmeciliği Dergisi 13/2 (2016), 103122.

Yetim, Gözde. Sağlıkı Yaşlanma Temelli Planlı Davranış Teorisi, Niyet ve Davranış İlişkisi. Eskişehir: Anadolu Üniversitesi Sosyal Bilimler Enstitüsü Spor Yöneticiliği Anabilim Dalı, Doktora Tezi, 2019. 
110

Journal of Analytic Divinity, Cilt/Vol: 5, Sayı/Issue: 1, 2021, ss/pp. 89-110.

Yazır, Elmalılı Hamdi. Hak Dini Kur'an Dili. 6 cilt. İstanbul: Eser Neşriyat ve DağıtımMasaüstü Yayınc1lık, 1993.

Yıldız, İbrahim. “Kur'an-1 Kerim'de Atalar Geleneği ve İnanca Etkisi”. KSÜ İlahiyat Fakültesi Dergisi 26 (2015), 175-216.

Yüzüak, Ahmet Volkan. Fen bilimleri öğretmen adaylarının sürdürülebilir davranışlarının planlanmış davranış teorisi temelinde değerlendirilmesi. Ankara: Hacettepe Üniversitesi Sosyal Bilimler Enstitüsü, Doktora Tezi, 2017.

Zeydân, Abdülkerim. "İslam'a Göre Sadece Niyet”. çev. Hasan Güleç. Diyanet Dergisi 15/4 (1976), 216-228. 